Acta Crystallographica Section F

Structural Biology

and Crystallization

Communications

ISSN 1744-3091

\section{Crystallization of domains involved in self-assembly of the S-layer protein SbsC}

\section{Anđela Dordić, ${ }^{a}$ Eva M. Egelseer, ${ }^{b}$ Manfred Tesarz, ${ }^{b}$ Uwe B. Sleytr, ${ }^{b}$ Walter Keller ${ }^{a}$ and Tea Pavkov-Keller ${ }^{\mathrm{a}, \mathrm{c} *}$}

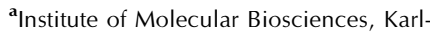
Franzens University Graz, Humboldtstrasse 50, 8010 Graz, Austria, 'b Department of Nanobiotechnology, University of Natural Resources and Life Sciences, Muthgasse 11, 1190 Vienna, Austria, and ${ }^{\mathrm{C}} \mathrm{ACIB}$ (Austrian Centre of Industrial Biotechnology) $\mathrm{GmbH}$, Petersgasse 14, 8010 Graz, Austria

Correspondence e-mail: tea.pavkov@uni-graz.at

Received 3 September 2012 Accepted 11 October 2012

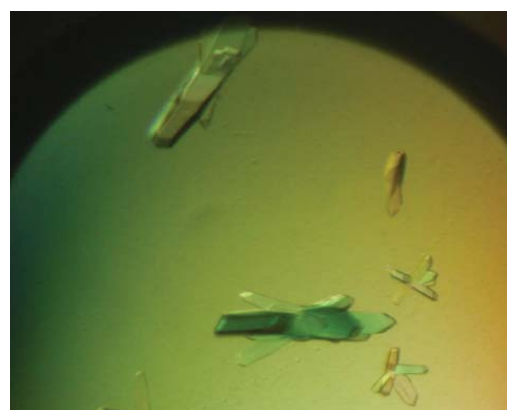

The Gram-positive bacterium Geobacillus stearothermophilus ATCC 12980 is completely covered with a two-dimensional crystalline monolayer composed of the S-layer protein SbsC. In order to complete the structure of the full-length protein, additional soluble constructs containing the crucial domains for selfassembly have been successfully cloned, expressed and purified. Crystals obtained from three different recombinant constructs yielded diffraction to 3.4, 2.8 and $1.5 \AA$ resolution. Native data have been collected.

\section{Introduction}

Crystalline bacterial cell-surface layers, termed S-layers, represent an almost universal feature of archaeal cell envelopes and have been identified in hundreds of different species of bacteria (Sleytr, 1978; Sleytr \& Beveridge, 1999). They can be regarded as the simplest protein membrane developed during evolution. S-layers, in general, are monomolecular isoporous structures composed of a single protein or glycoprotein species with a molecular mass in the range 40200 kDa (Sleytr, 1978; Sleytr \& Beveridge, 1999; Sleytr \& Messner, 2009). Electron-microscopic studies revealed that S-layer lattices can exhibit either oblique $(p 1, p 2)$, square $(p 4)$ or hexagonal $(p 3, p 6)$ symmetry, with a centre-to-centre spacing of the morphological units of approximately 3-35 nm (Pavkov-Keller et al., 2011; Sleytr et al., 1999).

Despite their ubiquitous appearance and their obvious importance in many prokaryotic organisms, the role of S-layers in nature is not completely clear. However, it is now recognized that S-layer lattices can provide the organism with a selective advantage by fulfilling a broad spectrum of functions (Beveridge, 1994; Beveridge \& Koval, 1993; Sára \& Egelseer, 1996; Sleytr et al., 1993, 1999; Sleytr \& Sára, 1997). Owing to their self-assembly ability, S-layers can be exploited as a patterning element for many nanobiotechnological applications (Egelseer et al., 2010; Ilk et al., 2011; Sleytr et al., 2005, 2007, 2010, 2011).

The protein precursor of the oblique lattice-forming S-layer protein SbsC from Geobacillus stearothermophilus ATCC 12980 (Egelseer et al., 1996) consists of 1099 amino acids including a 30-amino-acid-long Gram-positive signal peptide (UniProt O68840; Jarosch et al., 2000). Based on the gene sequence, different $\mathrm{N}$ - or $\mathrm{C}$-terminally truncated S-layer protein constructs have been recombinantly produced and systematically surveyed for their self-assembly and recrystallization properties (Jarosch et al., 2001). These studies confirmed that the N-terminal part comprising amino acids 31-258 is exclusively responsible for cell-wall binding, whereas the larger, C-terminal part comprises the self-assembly domain responsible for the formation of the crystalline array. This result has been corroborated by surface plasmon resonance (SPR) and isothermal titration calorimetry (ITC) studies showing that the positively charged $\mathrm{N}$-terminal region of $\mathrm{SbsC}$ binds specifically to a negatively charged secondary cell-wall polymer (SCWP; Ferner-Ortner et al., 2007; Pavkov et al., 2008).

The property of S-layer proteins to self-assemble into twodimensional crystals makes them very demanding candidates for structural studies. The crystallization and/or X-ray structures of several bacterial and archaeal truncated and soluble S-layer 
Table 1

Oligonucleotide primer pairs used for PCR amplification of the gene sequences encoding the various rSbsC truncations.

Overhangs are underlined, restriction sites are shown in bold and start and stop codons are shown in italics.

\begin{tabular}{|c|c|c|}
\hline rSbsC truncation & Primer names & Primer sequence $\left(5^{\prime}\right.$ to $\left.3^{\prime}\right)$ \\
\hline \multirow{2}{*}{$\mathrm{rSbsC}_{(31-761)}$} & rSbsC-31-forw & CGGAATTCCATGGCAACGGACGTGGCGAC \\
\hline & rSbsC-761-rev & GACCGCTCGAGTTATTTTAATGTAGTATCGATGACTTCAAC \\
\hline \multirow[t]{2}{*}{$\operatorname{rSbsC}_{(31-754)}$} & rSbsC-31-forw & 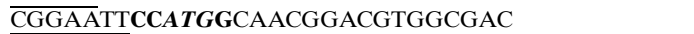 \\
\hline & rSbsC-754-rev & GACCGCTCGAGTTATTCAACATCTACAGTACCTAGAG \\
\hline \multirow[t]{2}{*}{$\mathrm{rSbsC}_{(31-790)}$} & rSbsC-31-forw & CGGAATTCCATGGCAACGGACGTGGCGAC \\
\hline & rSbsC-790-rev & GACCGCTCGAGTTATAAGTTAGCTAGTAACTTAGCTAAAG \\
\hline \multirow[t]{2}{*}{$\mathrm{rSbsC}_{(447-754)}$} & rSbsC-447-forw & CGGAATTCCATGGCAGAAGTTAGTGAATTAAAATTAACT \\
\hline & rSbsC-754-rev & GACCGCTCGAGTTATTCAACATCTACAGTACCTAGAG \\
\hline \multirow{2}{*}{$\mathrm{rSbsC}_{(443-650)}$} & rSbsC-443-forw & CGGAATTCCATGGATGAAAAAGCTGCAGAAGTTAG \\
\hline & rSbsC-650-rev & GACCGCTCGAGTTATACTGGTCCGCCAGCAAC \\
\hline \multirow{2}{*}{$\mathrm{rSbsC}_{(541-759)}$} & rSbsC-541-forw & CGGAATTCCATGGTTACTAAGACAATCCCTGTGAC \\
\hline & rSbsC-759-rev & GACCGCTCGAGTTATGTAGTATCGATGACTTCAACATC \\
\hline
\end{tabular}

constructs that have been reported to date are as follows: N-terminal and C-terminal parts of SbsC from G. stearothermophilus ATTC 12980 (Kroutil et al., 2009; Pavkov et al., 2003, 2008), a truncated derivative of the low-molecular-weight (LMW) S-layer protein from Clostridium difficile (Fagan et al., 2009), the cell-wall-binding domain of the Sap protein from Bacillus anthracis comprised of three S-layer homology (SLH) motifs (Kern et al., 2011) and polypeptide chain constructs from the archaeal surface-layer proteins from Staphylothermus marinus (Stetefeld et al., 2000), Methanosarcina mazei (Jing et al., 2002) and M. acetivorans (Arbing et al., 2012). Recently, the $\mathrm{X}$-ray structure of the S-layer protein SbsB from G. stearothermophilus PV72/p2 lacking the cell-wall-binding domain was reported (Baranova et al., 2012). The protein was crystallized in the presence of a nanobody as a crystallization chaperone preventing the selfassembly of the protein into two-dimensional crystals.

In order to complete the atomic structure of SbsC, we performed crystallization with different soluble truncation forms containing the domains responsible for self-assembly (Fig. 1).

\section{Materials and methods}

\subsection{Cloning, expression and purification}

The truncation constructs $\mathrm{rSbsC}_{(31-761)}, \mathrm{rSbsC}_{(31-754)}, \mathrm{rSbsC}_{(31-790)}$, $\operatorname{rSbsC}_{(447-754)}, \operatorname{rSbsC}_{(443-650)}$ and $\operatorname{rSbsC}_{(541-759)}$ were cloned and expressed according to published protocols (Jarosch et al., 2001; Kroutil et al., 2009). In brief, the gene sequences encoding the truncations were PCR-amplified using the respective oligonucleotide primers (given in Table 1), which introduced the restriction sites NcoI

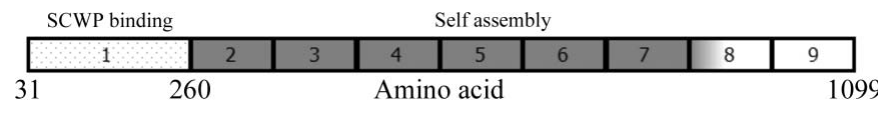

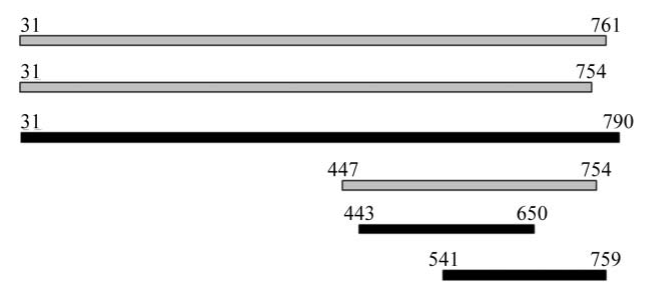

$$
\begin{aligned}
& \operatorname{rSbsC}_{(31-761)} \\
& \operatorname{rSbsC}_{(31-754)} \\
& \operatorname{rSbsC}_{(31-790)} \\
& \operatorname{rSbsC}_{(447-754)} \\
& \operatorname{rSbsC}_{(443-650)} \\
& \operatorname{rSbsC}_{(541-759)}
\end{aligned}
$$

Figure 1

Graphical representation of full-length rSbsC with domains indicated. The SCWP binding domain is marked with dots and domains involved in self-assembly are shown in dark grey. Constructs for which diffraction-quality crystals were obtained are coloured black, whereas constructs that did not yield crystals are coloured light grey. (including an ATG start codon) and XhoI at the $5^{\prime}$ and $3^{\prime}$ ends, respectively. For cloning, the resulting PCR products were ligated with plasmid pET28a+ (Novagen) and the recombinant plasmids were electroporated into Escherichia coli TG1 (Stratagene). For expression, the plasmids were established in E. coli One Shot BL21 Star (Invitrogen). Purification of the recombinant proteins was performed by fractionated ammonium sulfate precipitation and sizeexclusion chromatography as described by Pavkov et al. (2003), except that the lyophilization steps between the chromatography runs were omitted. Purified constructs were dialyzed against $50 \mathrm{mM}$ Tris$\mathrm{HCl} \mathrm{pH} 7.2$ and stored at $277 \mathrm{~K}$. The proteins were highly soluble and no degradation was observed within a period of six months.

\subsection{Crystallization}

Initial crystal screening and optimization trials for all constructs were performed with an Oryx8 robot (Douglas Instruments) using commercially available Index (Hampton Research) and Morpheus (Molecular Dimensions Ltd; Gorrec, 2009) screens. All screens and optimization setups were performed in Douglas vapour-batch plates (Douglas Instruments), which were covered with $3 \mathrm{ml}$ of an oil mixture consisting of paraffin (Merck) and silicone oil (SigmaAldrich) in a 3:1 ratio. Drops of $1 \mu \mathrm{l}$ were pipetted for both initial screens and optimizations. For initial screening, a 1:1 ratio of protein and commercial screening solutions was used. Optimization experiments included variation of this ratio as well as variation of the concentrations of the different screening-solution components. Crystallization plates were incubated at $293 \mathrm{~K}$, with the exceptions of those for $\mathrm{rSbsC}_{(443-650)}$ and $\mathrm{rSbsC}_{(541-759)}$, which gave better crystals at $289 \mathrm{~K}$.

Crystallization of $\mathrm{rSbsC}_{(31-790)}$ using a protein stock solution at $2.5 \mathrm{mg} \mathrm{ml}^{-1}$ in $50 \mathrm{~m} M$ Tris- $\mathrm{HCl} \mathrm{pH} 7.2$ gave several crystals of similar morphology (Fig. 2a), all of which yielded the same unit-cell parameters after indexing. The best diffracting crystal appeared after twoand-a-half weeks in optimized Morpheus condition 1-46 [5.2\%(w/v) PEG $8000,10.5 \%(v / v)$ ethylene glycol, $0.05 M$ Bicine/Trizma base $\mathrm{pH}$ 8.5 and $0.01 M$ each of 1,6-hexanediol, 1-butanol, $(R S)$-1,2-propanediol, 2-propanol, 1,4-butanediol and 1,3-propanediol] with a protein end concentration of $0.75 \mathrm{mg} \mathrm{ml}^{-1}$ corresponding to $30 \%$ protein solution in the drop.

Crystals of $\mathrm{rSbsC}_{(443-650)}$ obtained using a protein stock solution at $5.5 \mathrm{mg} \mathrm{ml}^{-1}$ in $50 \mathrm{~m} M$ Tris- $\mathrm{HCl} \mathrm{pH} 7.2$ appeared after five-and-a-half weeks under optimized Index condition No. 40 [0.01 $M$ citric acid $\mathrm{pH} 3.5,3.0 \%(w / v)$ PEG 3350] with an end protein concentration of $2.25 \mathrm{mg} \mathrm{ml}^{-1}$ in the drop (Fig. $2 b$ ).

Several conditions yielded crystals of $\mathrm{rSbsC}_{(541-759)}$ with octahedral morphology and with varying size and quality (Fig. $2 c$ ). The protein 
Table 2

Data-collection and processing statistics.

Values in parentheses are for the outer resolution shell.

\begin{tabular}{|c|c|c|c|c|}
\hline & $\operatorname{rSbsC}_{(31-790)}$ & $\mathrm{rSbsC}_{(443-650)}$ & $\operatorname{rSbsC}_{(541-759)}$ & $\mathrm{rSbsC}_{(541-759)}+\mathrm{Ca}^{2+}$ \\
\hline Beamline & PXI [microfocus], SLS & PXI [microfocus], SLS & PXIII, SLS & PXIII, SLS \\
\hline Wavelength $(\AA)$ & 1.0 & 1.0 & 1.0 & 1.0 \\
\hline Detector & MAR CCD 225 mm & MAR CCD $225 \mathrm{~mm}$ & PILATUS 2M & PILATUS 2M \\
\hline Unit-cell parameters $\left(\AA,^{\circ}\right)$ & $\begin{array}{c}a=57.2, b=98.3, c=109.3 \\
\alpha=\gamma=90, \beta=94.5\end{array}$ & $\begin{array}{c}a=b=110.3, c=87.2 \\
\alpha=\beta=\gamma=90\end{array}$ & $\begin{array}{c}a=b=106.9, c=110.5 \\
\alpha=\beta=\gamma=90\end{array}$ & $\begin{array}{c}a=49.1, b=43.8, c=49.7 \\
\alpha=\gamma=90, \beta=103.8\end{array}$ \\
\hline Space group & $P 2_{1}$ & $P 4_{1} 2_{1} 2$ & $P 4_{1} 2_{1} 2$ & $P 2_{1}$ \\
\hline Resolution limits $(\AA \stackrel{\circ}{)}$ & $19.9-3.4(3.49-3.40)$ & $30-2.6(2.70-2.60)$ & $49.1-3.4(3.61-3.40)$ & $48.3-1.54(1.64-1.54)$ \\
\hline$R_{\text {meas }}(\%)$ & $11.6(46.9)$ & $16.4(44.2)$ & $4.4(30.9)$ & $5.0(35.0)$ \\
\hline$R_{\text {merge }}(\%)$ & $10.6(42.9)$ & $15.3(39.2)$ & $3.9(27.5)$ & $4.2(29.0)$ \\
\hline Total No. of observations & $103011(7638)$ & $94566(5440)$ & $78216(12410)$ & $197022(28684)$ \\
\hline Total No. of unique reflections & $16664(1225)$ & $14641(1365)$ & $16772(2665)$ & $58519(9177)$ \\
\hline$\langle I / \sigma(I)\rangle$ & $14.8(5.1)$ & $10.8(3.2)$ & $25.7(5.8)$ & $15.7(3.0)$ \\
\hline Completeness (\%) & $99.4(99.8)$ & $85.5(77.1)$ & $99.4(97.7)$ & $98.8(95.7)$ \\
\hline Multiplicity & $6.2(6.2)$ & $6.5(4.0)$ & $4.7(4.7)$ & $3.4(3.1)$ \\
\hline Wilson $B$ factor $\left(\AA^{2}\right)$ & 58.6 & 38.6 & 96.1 & 27.2 \\
\hline Matthews coefficient $\left(\AA^{3} \mathrm{Da}^{-1}\right)$ & 3.8 & 3.1 & 3.2 & 2.3 \\
\hline Molecules per asymmetric unit & 1 & 2 & 2 & 1 \\
\hline Solvent content $(\%)$ & 67.5 & 60.8 & 61.7 & 46.6 \\
\hline
\end{tabular}

concentration of the stock solution was $6.4 \mathrm{mg} \mathrm{ml}^{-1}$ in $50 \mathrm{~m} M$ Tris$\mathrm{HCl} \mathrm{pH}$ 7.2. Crystals appeared after two-and-a-half weeks in optimized Index condition No. 95 [0.04 $M$ potassium thiocyanate, $12.7 \%(w / v)$ PEG MME 2000] with a protein concentration of $3.2 \mathrm{mg} \mathrm{ml}^{-1}$ in the drop. Initial optimization setups were repeated with the same protein solution containing $2 \mathrm{mM} \mathrm{CaCl} 2$. Most of these crystals appeared after four weeks. Compared with previous crystals of this truncation form, the new crystals exhibited a different morphology (Fig. 2d). The plate-like crystals showed mostly twinned or smeared spots in one direction. A complete data set was collected from a thicker plate-like crystal showing isotropic diffraction to $1.5 \AA$ resolution. This crystal grew from a condition consisting of $0.05 \mathrm{M}$ potassium thiocyanate, 13.8\%(w/v) PEG MME 2000.

\subsection{Data collection and processing}

Data collection from all crystals was performed at $100 \mathrm{~K}$ without additional cryoprotectant, since no ice rings were observed. Data sets from all truncation forms were collected on synchrotron beamlines (EMBL Outstation, Hamburg, Germany and Swiss Light Source, Villigen, Switzerland). Data sets were processed and scaled using the $X D S$ program package (Kabsch, 2010). The unit-cell parameters, assigned space groups and data statistics of the best data set for each truncation form are shown in Table 2. The number of molecules in the asymmetric unit was derived from the self-rotation function calculated with MOLREP (Vagin \& Teplyakov, 2010) as well as the approximate solvent content (Table 2).

\section{Results and discussion}

The structures of two SbsC C-terminal truncation constructs and the successful crystallization of the $\mathrm{N}$-terminally truncated construct $\mathrm{rSbsC}_{(755-1099)}$ have been reported previously (Pavkov et al., 2008; Kroutil et al., 2009). The structure of $\operatorname{rSbsC}_{(31-443)}$, containing the first three N-terminal domains, has been determined to $2.4 \AA$ resolution

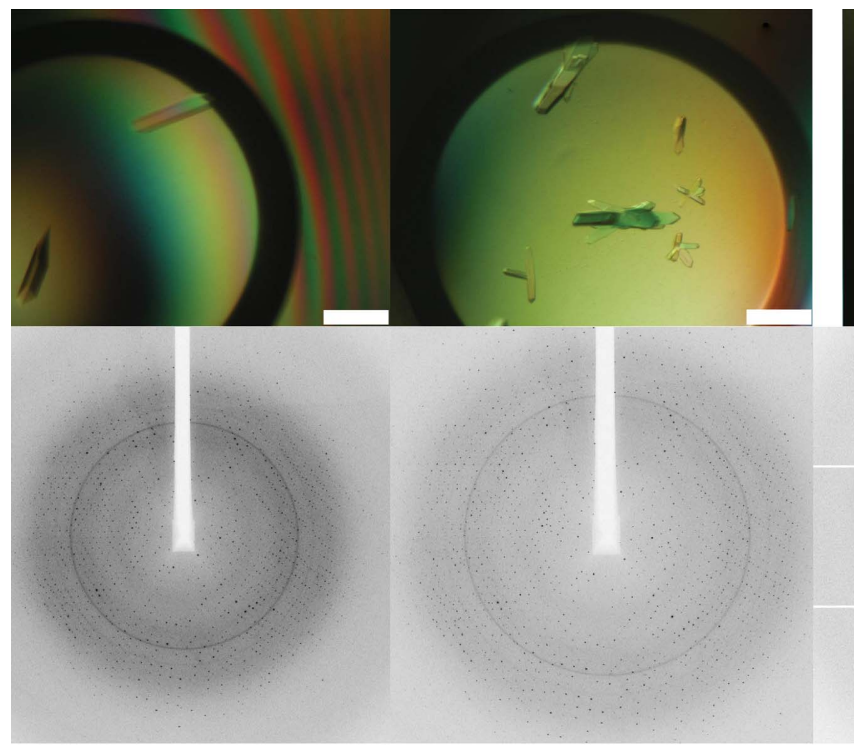

(a) (b)

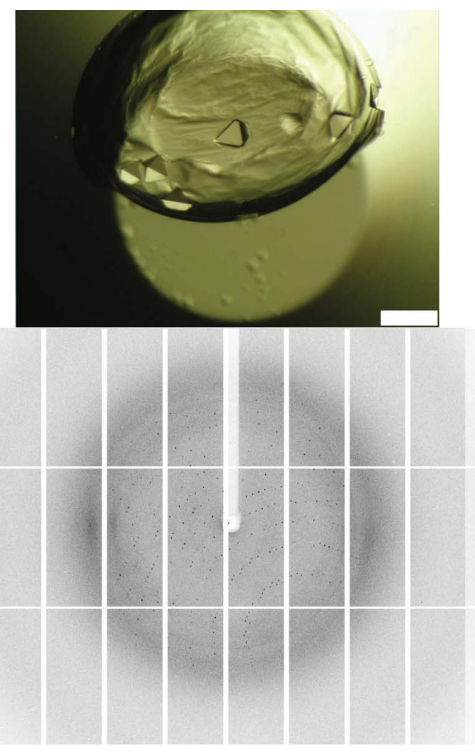

(c)

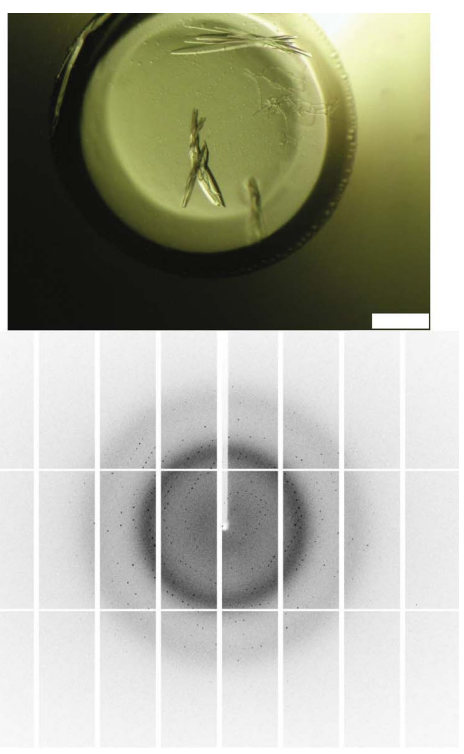

(d)

Figure 2

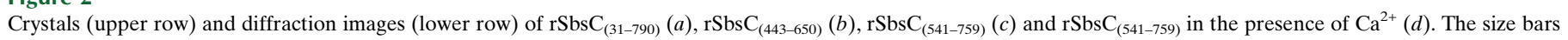
represent $0.2 \mathrm{~mm}$. 
(PDB entry 2ra1; Pavkov et al., 2008). The structure of a longer construct $\mathrm{rSbsC}_{(31-844)}$ was at a low resolution and was only partially interpretable. Thus, domain-level information could be derived, but large parts of the structure could only be built as a poly-Ala model. Therefore, two new C-terminal truncation forms of similar length, $\mathrm{rSbsC}_{(31-761)}$ and $\mathrm{rSbsC}_{(31-754)}$, including domains 1-6, were produced. However, these forms yielded no crystals. Owing to the fact that the partial structure of $\mathrm{rSbsC}_{(31-844)}$ showed that the observed ring-like structure is stabilized by extra residues from domain 7 (Pavkov et al., 2008), a new longer construct $\mathrm{rSbsC}_{(31-790)}$ was produced, for which crystals could be obtained. At the same time, constructs consisting of domains 4-5, 5-6 and 4-6 were subjected to crystallization. Diffraction-quality crystals were obtained for the first two constructs, $\mathrm{rSbsC}_{(443-650)}$ and $\mathrm{rSbsC}_{(541-759)}$. No crystals were obtained for the construct $\mathrm{rSbsC}_{(447-754)}$. It appears that the existence of two flexible linkers between the three domains is detrimental to the formation of an ordered crystal lattice.

A search for structures with significant sequence homology to domains 4, 5 and 6 failed. Therefore, molecular replacement was performed using poly-Ala models of individual domains 4, 5 and 6 from $\mathrm{rSbsC}_{(31-844)}$ (Pavkov et al., 2008). For all three truncation constructs, molecular replacement was performed with Phaser (McCoy et al., 2007). Manual inspection of the results obtained using Phaser confirmed that $\mathrm{rSbsC}_{(31-790)}$ contains one molecule in the asymmetric unit, $\mathrm{rSbsC}_{(443-650)}$ contains two molecules in the asymmetric unit and $\mathrm{rSbsC}_{(541-759)}$ plus $\mathrm{Ca}^{2+}$ contains one molecule in the asymmetric unit. No clear solution could be obtained using data from $\mathrm{rSbsC}_{(541-759)}$ without $\mathrm{Ca}^{2+}$. We believe that the high flexibility of some loop and/or linker regions in the absence of $\mathrm{Ca}^{2+}$ hampers the formation of stable crystal contacts.

Rebuilding and refinement of the structures is in progress and upon completion will yield the complete structure of the full-length SbsC protein.

This work was funded by projects J2841, P17885-N11 and P19794B12 from the Austrian Science Fund (FWF). EME was supported by the US Air Force Office of Scientific Research (AFOSR) project FA9550-10-1-0223. TP-K was supported by the Federal Ministry of Economy, Family and Youth (BMWFJ), the Federal Ministry of Traffic, Innovation and Technology (bmvit), the Styrian Business Promotion Agency SFG, the Standortagentur Tirol and ZIT Technology Agency of the City of Vienna through the COMET Funding Program managed by the Austrian Research Promotion Agency FFG.

\section{References}

Arbing, M. A., Chan, S., Shin, A., Phan, T., Ahn, C. J., Rohlin, L. \& Gunsalus, R. P. (2012). Proc. Natl Acad. Sci. USA, 109, 11812-11817.

Baranova, E., Fronzes, R., Garcia-Pino, A., Van Gerven, N., Papapostolou, D., Péhau-Arnaudet, G., Pardon, E., Steyaert, J., Howorka, S. \& Remaut, H. (2012). Nature (London), 487, 119-122.
Beveridge, T. J. (1994). Curr. Opin. Struct. Biol. 4, 204-212.

Beveridge, T. J. \& Koval, S. F. (1993). Advances in Bacterial Paracrystalline Surface Layers. New York: Plenum.

Egelseer, E. M., Ilk, N., Pum, D., Messner, P., Schäffer, C., Schuster, B. \& Sleytr, U. B. (2010). The Encyclopedia of Industrial Biotechnology: Bioprocess, Bioseparation and Cell Technology, edited by M. C. Flickinger, pp. 4424-4448. Hoboken: John Wiley \& Sons.

Egelseer, E. M., Schocher, I., Sleytr, U. B. \& Sára, M. (1996). J. Bacteriol. 178, 5602-5609.

Fagan, R. P., Albesa-Jové, D., Qazi, O., Svergun, D. I., Brown, K. A. \& Fairweather, N. F. (2009). Mol. Microbiol. 71, 1308-1322.

Ferner-Ortner, J., Mader, C., Ilk, N., Sleytr, U. B. \& Egelseer, E. M. (2007). J. Bacteriol. 189, 7154-7158.

Gorrec, F. (2009). J. Appl. Cryst. 42, 1035-1042.

Ilk, N., Egelseer, E. M. \& Sleytr, U. B. (2011). Curr. Opin. Biotechnol. 22, 824-831.

Jarosch, M., Egelseer, E. M., Huber, C., Moll, D., Mattanovich, D., Sleytr, U. B. \& Sára, M. (2001). Microbiology, 147, 1353-1363.

Jarosch, M., Egelseer, E. M., Mattanovich, D., Sleytr, U. B. \& Sára, M. (2000). Microbiology, 146, 273-281.

Jing, H., Takagi, J., Liu, J., Lindgren, S., Zhang, R., Joachimiak, A., Wang, J. \& Springer, T. A. (2002). Structure, 10, 1453-1464.

Kabsch, W. (2010). Acta Cryst. D66, 125-132.

Kern, J., Wilton, R., Zhang, R., Binkowski, T. A., Joachimiak, A. \& Schneewind, O. (2011). J. Biol. Chem. 286, 26042-26049.

Kroutil, M., Pavkov, T., Birner-Gruenberger, R., Tesarz, M., Sleytr, U. B., Egelseer, E. M. \& Keller, W. (2009). Acta Cryst. F65, 1042-1047.

McCoy, A. J., Grosse-Kunstleve, R. W., Adams, P. D., Winn, M. D., Storoni, L. C. \& Read, R. J. (2007). J. Appl. Cryst. 40, 658-674.

Pavkov, T., Egelseer, E. M., Tesarz, M., Svergun, D. I., Sleytr, U. B. \& Keller, W. (2008). Structure, 16, 1226-1237.

Pavkov, T., Oberer, M., Egelseer, E. M., Sára, M., Sleytr, U. B. \& Keller, W. (2003). Acta Cryst. D59, 1466-1468.

Pavkov-Keller, T., Howorka, S. \& Keller, W. (2011). Prog. Mol. Biol. Transl. Sci. 103, 73-130.

Sára, M. \& Egelseer, E. M. (1996). Crystalline Bacterial Cell Surface Proteins, edited by U. B. Sleytr, P. Messner, D. Pum \& M. Sára, pp. 103-131. Austin: R. G. Landes Co.

Sleytr, U. B. (1978). Int. Rev. Cytol. 53, 1-62.

Sleytr, U. B. \& Beveridge, T. J. (1999). Trends Microbiol. 7, 253-260.

Sleytr, U. B., Egelseer, E. M., Ilk, N., Messner, P., Schäffer, C., Pum, D. \& Schuster, B. (2010). Prokaryotic Cell Wall Compounds - Structure and Biochemistry, edited by H. König, H. Claus \& A. Varma, pp. 459-481. Heidelberg: Springer.

Sleytr, U. B., Egelseer, E. M., Ilk, N., Pum, D. \& Schuster, B. (2007). FEBS J. 274, 323-334.

Sleytr, U. B. \& Messner, P. (2009). Encyclopedia of Microbiology, edited by M. Schaechter, pp. 89-98. San Diego: Academic Press/Elsevier Science.

Sleytr, U. B., Messner, P., Pum, D. \& Sára, M. (1993). Mol. Microbiol. 10, 911-916.

Sleytr, U. B., Messner, P., Pum, D. \& Sára, M. (1999). Angew. Chem. Int. Ed. Engl. 38, 1035-1054.

Sleytr, U. B. \& Sára, M. (1997). Trends Biotechnol. 15, 20-26.

Sleytr, U. B., Sára, M., Pum, D. \& Schuster, B. (2005). Supramolecular Polymers, edited by A. Ciferri, pp. 583-612. New York: Marcel Dekker.

Sleytr, U. B., Schuster, B., Egelseer, E. M., Pum, D., Horejs, C. M., Tscheliessnig, R. \& Ilk, N. (2011). Prog. Mol. Biol. Transl. Sci. 103, 277-352.

Stetefeld, J., Jenny, M., Schulthess, T., Landwehr, R., Engel, J. \& Kammerer, R. A. (2000). Nature Struct. Biol. 7, 772-776.

Vagin, A. \& Teplyakov, A. (2010). Acta Cryst. D66, 22-25. 